\title{
DUPLEX KORRÓZIÓÁLLÓ ACÉL DURVALEMEZEK HEGESZTÉSE
}

\section{WELDING OF DUPLEX STAINLESS STEEL THICK PLATES}

\author{
Uzonyi Sándor $^{1, \mathrm{a}}$, Asztalos Lilla ${ }^{1, \mathrm{~b}}$, Dobránszky János ${ }^{2, \mathrm{c}}$ \\ ${ }^{I}$ BME, Gépészmérnöki Kar, Anyagtudomány és Technológia Tanszék \\ 1111 Budapest, Müegyetem rakpart 3. Magyarország; +36 702487278 , \\ ${ }^{2}$ MTA-BME Kompozittechnológiai Kutatócsoport \\ 1111 Budapest, Müegyetem rakpart 3. Magyarország; +3614631934
}
a) uzonyi.sandor90@gmail.com;
b) asztalos.lilla92@gmail.com;
c)Dobranszky.Janos@eik.bme.hu

\begin{abstract}
Duplex stainless steels (DSS) are one of the modern stainless steels. Their name comes from their duplex microstructure, which contains about equal proportion of austenite and $\delta$-ferrite. DSS are typically alloyed with chromium, nickel, manganese, molybdenum and nitrogen and contain low carbon. Their excellent corrosion resistance and mechanical properties make them proper base material for almost any task, that is why it is important to have a suitable welding technology for these materials. They are hard to weld because of their duplex microstructure and high alloy content, which, together, make sensitive these alloys to undesirable precipitations. The heat input, the shielding gas and the welding consumable must be chosen wisely. Thick $(10 \mathrm{~mm})$ plate just like in this experiment, are harder to handle. Careless handling of the welding parameters can cause problems in the ferrite-austenite phase balance and because of that the mechanical properties and corrosion resistance cannot fulfil the requirements. This experiments aims to compare a few possible welding procedure designs according for the previous details.
\end{abstract}

Keywords: welding, stainless steel, duplex.

\section{Összefoglalás}

A duplex korrózióálló acélok a modern korrózióálló acélok egyik fajtája. Nevüket a kettős szövetszerkezetükről kapták, amely nagyjából fele-fele arányban ausztenitet és $\delta$-ferritet tartalmaz. Fő ötvözőik a króm, nikkel és mangán, emellett jelentékeny mennyiségü molibdént és nitrogént tartalmazhatnak, karbon tartalmuk alacsony. [1] Kiváló korrózióállóságuk és mechanikai tulajdonságaik miatt szinte minden feladatra alkalmasak, ezért fontos, hogy megfelelő hegesztéstechnológiát alkalmazzunk feldolgozásukhoz. Az ilyen anyagok hegesztése sok buktatót rejt, nagy ötvözötartalmuk és kettős szövetszerkezetük miatt. Hegesztés során fokozott odafigyelést igényel a fajlagos hőbevitel, a védőgáz, a hegsztőanyag és a sorközi hőmérséklet is. [2] Különösen igaz ez a kísérletben szereplő $10 \mathrm{~mm}$ vastag lemezekre és azok többsoros varrataira. E technológiai változók hanyag kezelése a ferrit-ausztenit arány felborulását eredményezhetik, aminek következtében az anyag elveszíti fent említett kedvező mechanikai és korrózióállósági tulajdonságait, intermetallikus fázisok keletkezhetnek, továbbá a szívósságcsökkenés veszélye is fennáll. [1] A dolgozat e szempontok figyelembe vételével hasonlítja öszsze a felmerülő hegesztési eljárásokat és ad ajánlást az ilyen anyagok megmunkálására.

Kulcsszavak: ívhegesztés, korrózióálló acél, duplex acél. 


\section{Célkitűzés}

A dolgozatot a duplex korrózióálló acélok hegesztésének kutatása céljával 2012ben indított program feladataihoz illeszkedve készítettük. Egy jelentős japán gyártómü biztosította a $10 \mathrm{~mm}$ vastag durvalemezeket a kísérletekhez. A kísérlet célja, hogy megfelelő hegesztési technológiát és élelőkészítési geometriát találjunk egy ilyen kényes anyagminőség hegesztéséhez, vagy legalább ajánlást adjunk arra, ,hogyan ne hegesszék".

\section{A kísérletekben használt alap- anyagok}

A kísérlet során három különböző duplex korrózióálló anyagot használtunk fel, egy standard duplex és kétféle sovány (angolul: lean) duplex acélt. Ezek viselkedését hasonlítottuk össze az eltérő hegesztési eljárások hatására. A Nippon Steel \& Sumikin Stainless Steel (továbbiakban: NSSC) japán acélgyártó az alábbi anyagokat bocsátotta rendelkezésünkre.

\section{$S 21013$}

Az Otokumpu LDX 2101 típusú duplex acél licence alatt gyártott acélminőség. Az LDX 2101 duplex acél hegesztéséről számos kutatás készült már a BME ATT-n, ennek hegesztésével az I. kísérletsorozatban nem foglalkoztunk.

DX1

Hagyományos duplex. A gyártó vegyszertartályok, erőmüi alkalmazások építéséhez ajánlja. Sajnos bővebb információt nem közöl róla a holnapján.

\section{NSSC2120}

Újfajta sovány duplex acél. Különlegessége, hogy nagy hőbevitellel járó eljárással is hegeszthető, mint például a fedett ívü hegesztés. Korrózióállósági és mechanikai tulajdonságaiban messze felülmúlja a közönséges ausztenites korrózióálló acélokat.

\section{Az első hegesztési kísérlet}

A duplex acélok hegesztése során a fajlagos hőbevitelt nem szabad sem túl kis sem túl nagy szinten tartani, ezek a határok alapanyagtól függenek. A nem megfelelő hőbevitelü hegesztés a fázisarány felborulásához, illetve nemkívánatos öregedési folyamatokhoz vezethet. Az öregedési folyamatok minimalizálásának érdekében a varratsorok számát is érdemes minél lentebb szorítani. [1] [2]

\subsection{A varratok elkészítése}

Az első hegesztési kísérlet során az általánosan elterjedt hegesztési technológiákat hasonlítottuk össze egymással, különbözö varratfelépítésben (1. ábra). A kísérlet során az alábbi kötéseket hegesztettük le:

1. táblázat. A kisérletekben alkalmazott eljárások kombinációi és a varratok felépitése

\begin{tabular}{|c|c|c|c|}
\hline Kísérlet & Acél & Eljárások & Felépítés \\
\hline $2-1$ & DX1 & $141+111$ & ss nb \\
\hline $3-1$ & 2120 & $141+111$ & ss nb \\
\hline $2-2$ & DX1 & $141+136$ & ss nb \\
\hline $2-3$ & DX1 & $141+136$ & bs \\
\hline $3-2$ & 2120 & $141+136$ & ss nb \\
\hline $3-3$ & 2120 & $141+136$ & bs \\
\hline
\end{tabular}

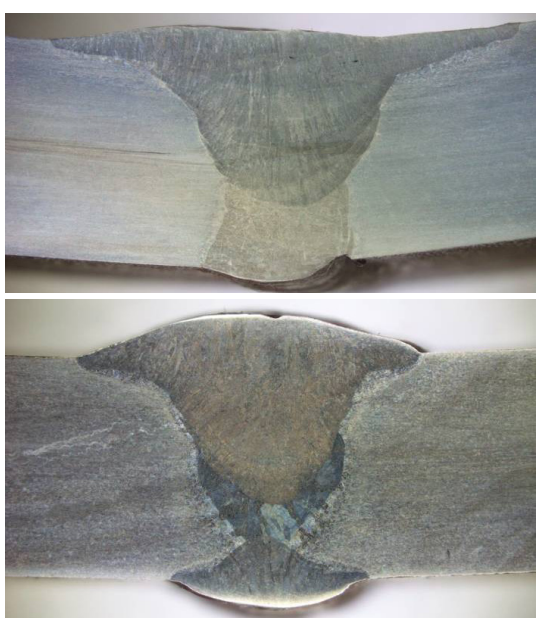

1. ábra. 2-1 és 3-3 kötés keresztmetszeti képe 
A volfrámelektródás semleges védőgázos ívhegesztést (141) csak a gyökvarratokhoz használtuk, míg a bevont elektródás kézi ívhegesztést (111) és a huzalelektródás aktív védőgázos ívhegesztést portöltetü huzallal (136) töltő- és takaróvarratokhoz. Az „ss $n b$ ” az egyoldali megtámasztás nélküli varratokat jelöli, míg a ,bs” a gyökutánhegesztéssel készülteket.

\subsection{A hegesztett kötések vizsgálata}

A kötéseket először vizuális vizsgálattal ellenőriztük: a nemmegfelelőségeket és az összeolvadási hiányosságokat kerestünk.

A duplex acélok varrataiban kulcsfontosságú a fázisok aránya, ezért a ferrittartalom ferritszkópos mérésével végeztük. A szonda nagy mérete miatt a hőhatásövezet (2. ábra) vizsgálata nem volt lehetséges.
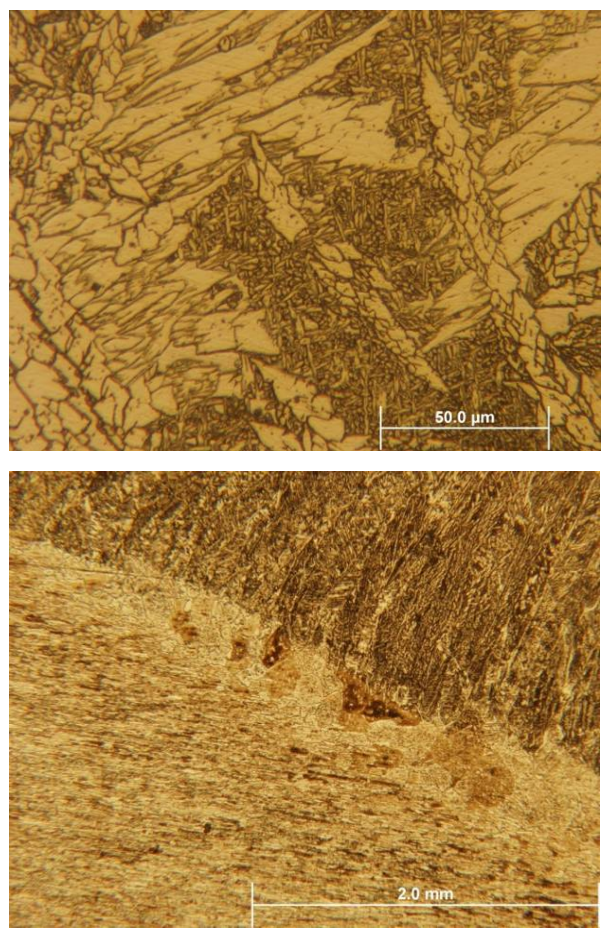

2. ábra. Porbeles huzalelektródával hegesztett töltövarrat finomszemcsés ausztenitje (fent) és a höhatásövezete az alapanyaggal (lent)
A varratok mikro- és makroszerkezetét csiszolatokon vizsgáltuk, amelyeken később mikrokeménységmérést végeztünk 100 gramm terheléssel.

\section{A második hegesztési kísérlet}

Az eredmények alapján a technológiát felülvizsgálva arra a következtetésre jutottunk, hogy a varratsorokat fajlagos hőbevitelük szempontjából csökkenő sorrendben kell hegeszteni. Ezt szem elött tartva megismételtük a hegesztési kísérleteket.

\subsection{A varratok hegesztése}

Mivel az 1. kísérletben az egyoldali varratok hegesztése nehézkes volt az ömledék nagy viszkozitása miatt, a TIG gyökhegesztés helyett, első lépésben csak 136-os eljárással készítettünk gyökutánhegesztett kötéseket (3. ábra). Ipari alkalmazásokban is inkább ez az eljárás elterjedt: ahol csak lehet, kétoldali varratokat alkalmaznak.

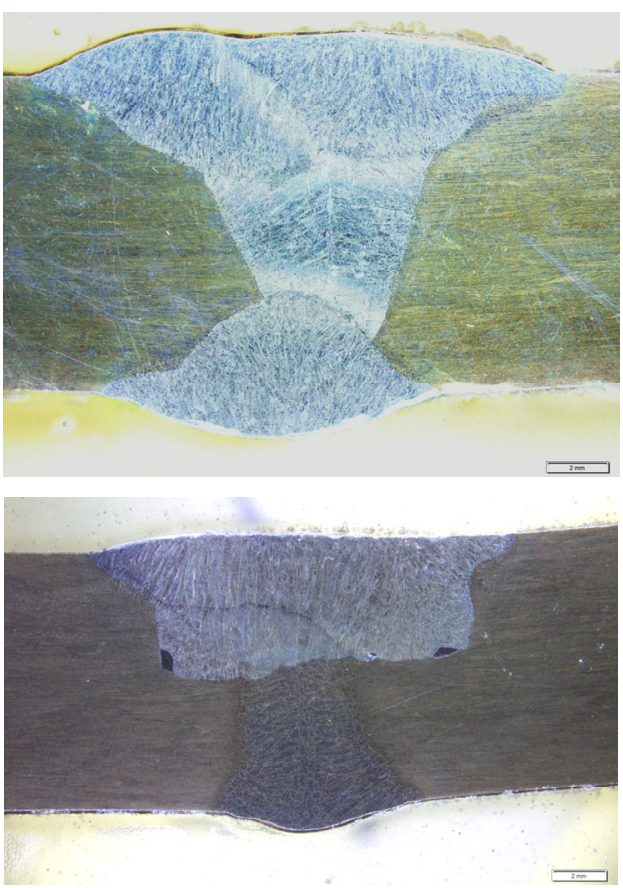

3. ábra. 3-4 és 3-5 kötés makró felvétele 
A varratsorok számának csökkentése érdekében kísérleteztünk az aktiválóporos volfrámelektródás (ATIG-) hegesztéssel is (3-5 és 3-6 próbatest). Az aktiválóporos hegesztés több elökészítési munkát igényel, és szinte teljesen kizárja a kézi hegesztés lehetőségét, ezért ezeket a varratokat lineáris hajtású hegesztőautomatán készítettük. Az aktiválópor szilícium-dioxid volt.

2. táblázat. A kisérletben felhasznált hegesztési eljárások kombinációi és a varratok felépitése

\begin{tabular}{|c|c|c|c|}
\hline Kísérlet & Acél & Eljárások & Felépítés \\
\hline $1-4$ & 2101 & 136 & bs \\
\hline $3-4$ & 2120 & 136 & bs \\
\hline $3-5$ & 2120 & $\mathrm{~A} 141+136$ & $\mathrm{ss} \mathrm{mb}$ \\
\hline $3-6$ & 2120 & $\mathrm{~A} 141+136$ & bs \\
\hline
\end{tabular}

\subsection{A kötések vizsgálata}

A második kísérletsorozatot az elsővel azonos vizsgálati metódusokkal értékeltük. A vizsgálati eredmények igazolni látszanak az első hegesztési kísérlet után felállított hipotézisünket.

Az aktiválóporos 141-es eljárással hegesztett varratok (4. ábra) kisebb keménysége valószínüleg arra vezethető vissza, hogy a varrat keresztmetszete igen nagy, ezért a szokványos varrathosszra fajlagosított hőbevitellel nem jellemezhető jól a folyamat.

Az ebben a kísérletsorozatban hegesztett varratok höhatás övezetének kilágyulása további vizsgálat tárgyát képezi.

\section{5. Összegzés}

Összegzésképpen megállapítható, hogy a célkitüzésben megfogalmazottakat teljesítettük. A tanulmány során több olyan pWPS is készült, amelyek akár valós gyártási feladatok megoldásához is szolgálhatnak kiindulási alapnak. A kísérletek folytatása során a hegesztett sorok további csökkentését tüztük ki célul magunk elé. Az anyagvizsgálatokat (15614-1-nek megfelelően) szakító, hajlító, ütőmunka és radiográfiás vizsgálattal; valamint pásztázó elektronmikroszkópos vizsgálattal kívánjuk kibővíteni.

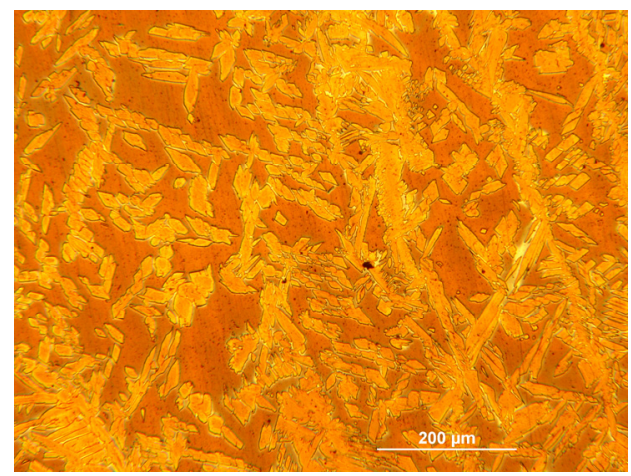

4. ábra. A 3-6 jelölésü kötés gyökének (ATIG) mikroszerkezete

\section{Köszönetnyilvánítás}

A szerzők köszönetüket fejezik ki a kísérleti programot támogató cégeknek azért, hogy rendelkezésre bocsátották a szükséges anyagokat: a japán Nippon Steel \& Sumikin Stainless Steel Corporation a $10 \mathrm{~mm}$ vastag duplex acél alapanyagokat, a az Outokumpu Kft. a tömör huzalt, a Corweld Kft. a bevonatos elektródát, a Böhler-Uddeholm Kft. a porbeles huzalt.

\section{Szakirodalmi hivatkozások}

[1] Songqing Wen: Metallurgical Evaluation of Cast Duplex Stainless Steels and Their Weldments, University of Tennessee Knoxville, 2001, 7-20, 46-60.

[2] M. Sadeghian, M. Shamanian, A. Shafyei: Effect of heat input on microstructure and mechanical properties of dissimilar joints between super duplex stainless steel and high strength low alloy steel. Materials and Design journal, Department of Materials Engineering, Isfahan University of Technology, Isfahan 8415683111, Iran. 2014.04.13. 